ISSN 2089-8673 (Print) | ISSN 2548-4265 (Online)

Volume 8, Nomor 2, Juli 2019

\title{
PENERAPAN MODEL PEMBELAJARAN KOOPERATIF TIPE PICTURE AND PICTURE UNTUK MENINGKATKAN MOTIVASI DAN HASIL BELAJAR PADA MATA PELAJARAN TIK DI SMP NEGERI 3 SERIRIT
}

\author{
Komag Mas Ariana ${ }^{1}$, Ketut Agustini ${ }^{2}$, I Gede Partha Sindu ${ }^{3}$ \\ Jurusan Pendidikan Teknik Informatika \\ Fakultas Teknik dan Kejuruan \\ Universitas Pendidikan Ganesha \\ Singaraja, Bali \\ e-mail: komangarianaa@gmail.com¹, ketutagustini@undiksha.ac.id ${ }^{2}$, \\ partha.sindu@undiksha.ac.id ${ }^{3}$
}

\begin{abstract}
Abstrak
Penelitian ini bertujuan untuk menganalisis peningkatan motivasi dan hasil belajar siswa pada mata pelajaran TIK kelas VIII B semester ganjil2017/2018 di SMP Negeri 3 Seririt melalui penerapan model pembelajaran kooperatif tipe Picture and Picture.Jenis penelitian merupakan penelitian tindakan kelas. Subjek penelitian adalah siswa kelas VIII B sebanyak 30 orang siswa. Objek penelitian adalah model pembelajaran kooperatif tipe Picture and Picture, motivasi dan hasil belajar. Penelitian ini dilaksanakan dalam dua siklus. Data motivasi belajar dikumpulkan dengan angket dan data hasil belajar dikumpulkan dengan tes. Data penelitian dianalisis secara deskriptif. Hasil analisis data menunjukkan 1) motivasi belajar siklus I dan II berada pada kategori positif. 2) Hasil belajar siswa pada siklus I berada pada kategori sedang, dan pada siklus II berada pada kategori baik. Penerapan model pembelajaran kooperatiftipe Picture and Picture dapat meningkatkan motivasi dan hasil belajar siswa kelas VIII B tahun pelajaran $2017 / 2018$.
\end{abstract}

Kata-kata kunci: Model Pembelajaran Kooperatif Tipe Picture and Picture, Motivasi Belajar, dan Hasil Belajar

\begin{abstract}
This study aimed to analyze the increase in motivation and student learning outcomes in ICT subjects grade VIII B odd semester 2017/2018 in Seririt 3 Public Middle School through the application of the Picture and Picture type cooperative learning model. This type of research is classroom action research. The research subjects were class VIII B as many as 30 students. The object of the research is the Picture and Picture cooperative learning model, motivation and learning outcomes. This research was conducted in two cycles. Learning motivation data is collected by questionnaire and learning outcome data is collected by tests. The research data were analyzed descriptively. The results of data analyze showed that 1) learning motivation in cycles I and II were in the positive category. 2) Student learning outcomes in the first cycle are in the moderate category, and in the second cycle are in the good category. The application of the Picture and Picture cooperative learning model can increase motivation and learning outcomes of class VIII B students in the school year 2017/2018.
\end{abstract}

Keywords: Cooperative learning, Picture and Picture Type, Learning Motivation, and Learning Achievement 


\section{PENDAHULUAN}

Pendidikan merupakan usaha sadar dan terencana untuk mewujudkan suasana belajar dan proses pembelajaran agar peserta didik secara aktif mengembangkan potensi dirinya untuk memiliki kekuatan spiritual keagamaan, pengendalian diri, kepribadian, kecerdasan, akhlak mulia, serta keterampilan yang diperlukan dirinya, masyarakat, bangsa, dan Negara (Pasal 1 UU RI No. 20 Tahun 2003 tentang Sistem Pendidikan Nasional). Salah satu masalah yang dihadapi dunia pendidikan formal (sekolah) adalah masalah lemahnya daya serap peserta didik dalam proses pembelajaran dan kurangnya fasilitas pendukung pembelajaran yang terdapat di sekolah. Dalam proses pembelajaran, anak kurang didorong untuk mengembangkan kemampuan berfikir. Proses pembelajaran didalam kelas diarahkan kepada kemampuan anak untuk menghafal informasi, otak anak dipaksa untuk mengingat dan menimbun berbagai informasi tanpa dituntut untuk memahami informasi yang diingatnya itu untuk menghubungkan dengan kehidupan sehari-hari. Akibatnya ketika anak didik lulus dari sekolah, mereka pintar secara teoritis, tetapi mereka miskin aplikasi (Sanjaya, 2006).

Miyono (2011:35) menyebutkan bahwa pentingnya mempelajari TIK dalam proses pembelajaran di sekolah khususnya di kelas adalah guna membuktikan pada masyarakat bahwa potensi teknologi informasi dan komunikasi dapat meningkatkan mutu pembelajaran. Teknologi informasi dan komunikasi (TIK), memiliki potensi yang sangat besar sebagai sarana atau alat untuk membangun berbagai keterampilan dalam proses pembelajaran. Menurut (Kurniasih, 2015) Adapun 3 kelebihan dari model Picture and Picture ini agar guru dapat dengan mudah mengetahui kemampuan masing-masing siswa, model Picture and Picture ini melatih siswa untuk berpikir logis dan sistematis, dapat membantu siswa berpikir kritis, dan dapat memunculkan motivasi belajar siswa kearah yang lebih baik. Menurut (Handayani, 2013), model pembelajaran Picture and Picture merupakan model pembelajaran yang menggunakan gambar yang dipasangkan ataupun diurutkan menjadi urutan yang logis. Prinsip pelaksanaan model pembelajaran Picture and Picture yaitu sajian informasi kompetensi, sajian materi, perlihatkan gambar yang berkaitan dengan materi, siswa mengurutkan gambar sehingga sistematik, guru mengkonfirmasi urutan gambar tersebut.

Kenyataanya, dalam pembelajaran TIK di sekolah guru yang seharusnya bertindak sebagai fasilitator, pengelola, pembimbing, dan motivator yang mampu membangkitkan motivasi siswa agar siswa senantiasa belajar denganbaik dan bersemangat belum dilaksanakan secaraoptimal.Keberhasilanpencapaian

kompetensi suatu mata pelajaran tergantung kepada beberapa aspek. Salah satu aspek yang sangat mempengaruhi adalah bagaimana seorang guru melaksanakan pembelajaran agar siswa dapat ikut terlibat aktif dalam proses pembelajaran. Hal ini selain disebabkan oleh kurangnya sarana dan mediapembelajaran yang menunjang ketercapaian tujuan pembelajaran. Berdasarkan catatan nilai yang dimiliki oleh guru TIK di Smp Negeri 3 Seririt ditemukan bahwa nilai rata-rata hasil belajar siswa kelas VII yang kini sudah menjadi kelas VIII masih di bawah KKM (Kriteria Ketuntasan Minimal) yang ditentukan di sekolah adalah 75. Hal tersebut dapat dilihat dari Nilai UAS (Ulangan Akhir Semester) yang dicapai siswa kelas VII semester genap pada mata pelajaran TIK tahun pelajaran 2016/2017 pada tabel 1.1. 
Tabel 1. 1 Nilai Rata-rata UAS Siswa Kelas VII Semester Genap pada Mata Pelajaran TIK Tahun Pelajaran 2016/2017

\begin{tabular}{|c|c|c|}
\hline Kelas & $\begin{array}{c}\text { Jumlah } \\
\text { Siswa } \\
\text { (orang) }\end{array}$ & $\begin{array}{c}\text { Ketuntasan } \\
\text { (\%) }\end{array}$ \\
\hline VII A & 31 & 9,67 \\
\hline VII B & 32 & 6,25 \\
\hline VII C & 31 & 16,12 \\
\hline VII D & 30 & 20 \\
\hline VII E & 32 & 9,37 \\
\hline Total & 156 & $20 \%$ \\
\hline
\end{tabular}

(Sumber: Guru Mata Pelajaran TIK SMP Negeri 3 Seririt)

Berdasarkan tabel di atas dapat dilihat, presentase hasil belajar siswa kelas VII masih rendah terutama pada kelas VII B ketuntasan klasikal kelasnya hanya mencapai $6,25 \%$ yang di dapat dengan rumus ( $\mathrm{KB}=$ Jumlah siswa nilainya $\geq 75 /$ jumlah seluruh siswa $\times 100 \%$ ) dan jika dikonversi ke pedoman acuan patokan (PAP) skala lima maka termasuk pada kriteria rendah.

Berdasarkan hasil observasi awal, wawancara dan hasil pengamatan langsung peneliti yang telah dilakukan di kelas VIII Khususnya kelas VIII B SMP Negeri3 Seririt terdapat beberapa permasalahan terkait dengan proses pembelajaran khususnya mata pelajaran Teknologi Informasi dan Komunikasi (TIK) yang berlangsung dalam suatu proses belajar mengajar di kelas diantaranya sebagai berikut. (1). Proses pembelajaran yang didominasi oleh pola pembelajaran konvensional yang didominasi metode ceramah. (2). Motivasi belajar siswa rendah sehingga siswa kurang aktif dalam mengikuti pembelajaran. (3). Kurangnya kegiatan praktikum mengakibatkan keterampilan siswadalammenggunakan komputer dan materi yang diajarakan didalamanya masih sangat rendah.

Salah satu model pembelajaran yangdapat diterapkan adalah model pembelajaran Picture and Picture. Karena Model Picture and Picture merupakan salah satu langkah yang dapat ditempuh untuk memperbaiki hasil belajar siswa. Menurut (Kurniasih, 2015) Adapun 3 kelebihan dari model Picture and Pictureini agar guru dapat dengan mudah mengetahui kemampuan masing-masing siswa, model Picture and Pictureini melatih siswa untuk berpikir logis dan sistematis, dapat membantu siswa berpikir kritis, dan dapat memunculkan motivasi belajar siswa kearah yang lebih baik. Menurut (Handayani, 2013), model pembelajaran Picture and Picture merupakan model pembelajaran yang menggunakan gambar yang dipasangkan ataupun diurutkan menjadi urutan yang logis. Prinsip pelaksanaan model pembelajaran Picture and Picture yaitu sajian informasi kompetensi, sajian materi, perlihatkan gambar yang berkaitan dengan materi, siswa mengurutkan gambar sehingga sistematik, guru mengkonfirmasi urutan gambar tersebut.

Berdasarkan uraian tersebut dapat disimpulkan bahwa model pembelajaran Picture And Picture merupakan model pembelajaran yang sesuai untuk mengatasi permasalahan yang dialami guru dan siswa pada saat proses belajar mengajar (PBM) dan hasil penelitian terkait menunjukkan bahwa terjadinya peningkatan motivasi serta hasil belajar siswa.

Tujuan penelitian ini adalah untuk memecahkan permasalahan yang telah dikemukakan. Secara rinci tujuan penelitian ini adalah sebagai berikut.

1. Meningkatkan motivasi belajar siswa pada mata pelajaran TIK kelas VIII B semester ganjil tahun ajaran 2017/2018 di SMP Negeri 3 Seririt melalui penerapan model pembelajaran kooperatif tipe Picture and Picture.

2. Meningkatkan hasil belajar siswa pada mata pelajaran TIK kelas VIII B semester ganjil 2017/2018 di SMP Negeri 3 Seririt melalui penerapan 
model pembelajaran kooperatif tipe

Picture and Picture.

\begin{tabular}{llrr} 
Model & Picture and & Picture \\
merupakan & salah satu & model \\
pembelajaran & \multicolumn{2}{c}{ kooperatif } & yang \\
menggunakan & gambar dengan cara \\
memasangkan atau mengelompokkan.
\end{tabular}

Model pembelajaran inimenuntut siswa untuk menciptakan suatu inovasi yang baru yang dapat mendorong kesenangan anak dengan belajar dari sebuah masalah serta menyelesaikannya sesuai dengan metode dan cara yang di miliki oleh setiap peserta didik yang didapat dari pembelajaran yang diperoleh dari proses pembelajaran Hamdani dalam (Sidauruk, 2016).

Motivasi belajar adalah dorongan internal dan eksternal pada siswa-siswa yang sedang belajar untuk mengadakan perubahan tingkah laku pada umumnya dengan beberapa indikator atau unsur yang mendukung yaitu motivasi intrinsik dan motivasi ekstrensik (Uno, 2008). Adapun indikator motivasi belajar intrinsik terdiri dari adanya hasrat dan keinginan berhasil, adanya dorongan dan kebutuhan dalam belajar, adanya harapan dan citacita masa depan.

Hasil belajar sangat erat kaitannya dengan belajar atau proses belajar. Hasil belajar pada sasarannya dikelompokkan dalam dua kelompok, yaitu pengetahuan dan keterampilan. Adapun indikator hasil belajar yang digunakan menurut taksonomi bloom yaitu Pengetahuan (C1), pemahaman (C2), aplikasi (C3), analisis (C4), sintesis (C5), dan evaluasi (C6) (Arikunto, 2012).

\section{METODE}

Penelitian ini dilaksanakan di SMP Negeri 3 Seririt pada kelas VIII B. Waktu pelaksanaan penelitian ini adalah rentangan waktu semester ganjil antara bulan Juli sampai dengan bulan November pada tahun ajaran 2017/2018.

Subjek penelitian tindakan kelas ini adalah siswa kelas VIII BNegeri 3 Seririt tahun pelajaran 2017/2018 sebanyak 30 siswa, yang terdiri dari 16 siswa perempuan dan 14 siswa laki-laki. Kelas VIII B dipilih sebagai subjek penelitian karena di kelas tersebut terungkap permasalahan-permasalahan yang telah diungkapkan pada bagian latar belakang. Objek penelitian kelas ini adalah motivasi dan hasil belajar siswa pada mata pelajaran TIK kelas VIII B dengan menerapkan model pembelajaran kooperatif tipe Picture and Picture.

Jenis penelitian yang digunakan adalah penelitian tindakan kelas (PTK). Penelitian tindakan kelas (PTK) ini direncanakan dalam dua siklus. Pada siklus pertama digunakan sebagai menerapkan model pembelajaran sehingga pada siklus satu prosesnya belum teramati dengan baik. Pada siklus kedua digunakan sebagai perbaikan pada siklus pertama dan proses penerapan model sudah dapat teramati dengan baik. Apabila pada siklus pertama telah mencapai kriteria keberhasilan yang ditetapkan, maka akan dilanjutkan pelaksanaan siklus kedua untuk dapat mengamati dengan baik proses penerapan model yang digunakan.Rancangan penelitian ini dapat ditunjukkan pada gambar 1.1 berikut. 


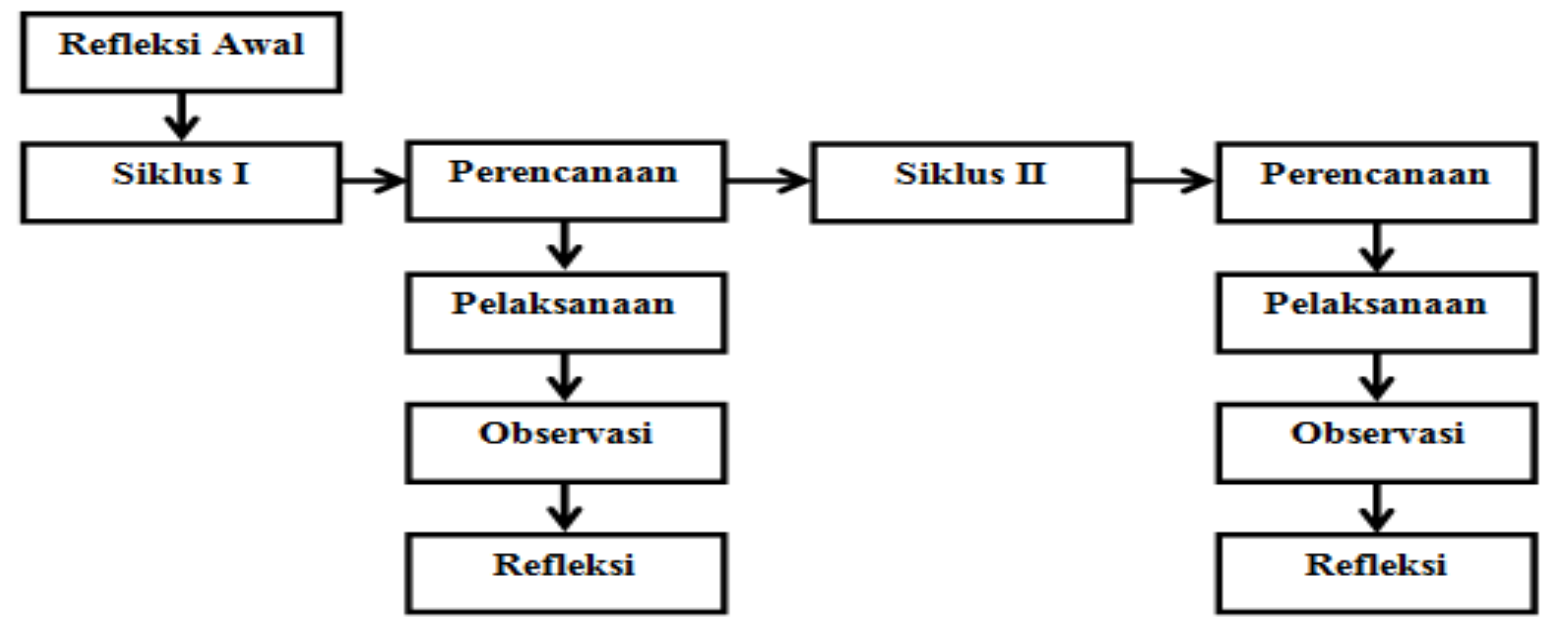

Gambar 1. Rancangan Penelitian Diadaptasi dari Model Penelitian Kemmis \& Taggart

1. Tahap Pelaksanaan Tindakan

Pada tahap perencanaan ini peneliti bersama guru pengajar di kelas VIII B menyusun tindakan sebagai acuan dalam pelaksanaan tindakan yaitu sebagai berikut. (a) Berkolaborasi dengan guru TIK untuk menentukan jadwal pelajaran yang disesuaikan dengan jadwal pelajaran di sekolah. (b) Menyamakan persepsi dengan guru bidang studi TIK kelas VIII mengenai implementasi model pembelajaran kooperatif tipe Picture and Picture pada pelajaran TIK di Kelas VIII B. (c) Bersama dengan guru bidang studi menyusun Rencana Pelaksanaan Pembelajaran (RPP) dilengkapi LKS yang dirancang dengan soal-soal pemecahan masalah yang langkah-langkah penyelesaiannya diarahkan pada implementasi model pembelajaran kooperatif tipe Picture and Picture untuk materi yang akan diajarkan. (d) Bersama dengan guru bidang studi menyiapkan media pembelajaran yang diperlukan berupa buku teks, media gambar, laptop dan lembar jawaban. (e) Membuat lembar kerja siswa dan soal tes (post-test). (f) Bersama dengan guru bidang studi menyusun instrument penelitian berupa lembar observasi yang akan digunakan untuk menilai hasil belajar siswa.

2. Tahap Pelaksanaan Tindakan
Dalam pelaksanaan tindakan ini, pembelajaran yang dilakukan mengacu sintaks model pembelajaran kooperatif tipe Picture and Picture yang sudah digambarkan pada rencana pelaksanaan pembelajaran yang telah disusun pada tahap perencanaan. Maka pada setiap pertemuan guru merencanakan (1) berdiskusi dengan guru pendamping tentang bagaimana mengembangkan pembelajaran modelkooperatif tipe Picture and Picture, (2) mengajak siswa berdiskusi atau bercakap-cakap tentang model Picture and Picture, (3) melaksanakan pembelajaran (memberi tindakan) dengan menggunakan gambar untuk meningkatkan motivasi dan hasil belajar siswa sesuai dengan perencanaan yang telah disiapkan. Kegiatan Pendahuluanyang dilakukan adalah membuka pelajaran dengan mengucapkan salam, berdoa, dan mengecek kehadiran siswa. Pendidik menyampaikan indikator pembelajaran terkait materi pembelajaran yang akan dipelajari. Pendidik mengamati kesiapan peserta didik sebelum mengikuti pemebelajaran dan memberikan motivasi agar siswa tertarik untuk mengikuti pembelajaran.Pada kegiatan inti dalam proses pembelajaran model problem based learning adalah sebagai berikut. (1) Pada tahap eksplorasipendidik 
memberikan materi pengantar, pendidik menyiapkan atau menyediakan gambar yang akan digunakan yang berkaitan dengan materi, dan pendidik membagi siswa dalam kelompok yang terdiri dari 5 orang dan memberikan LKS kepada masing-masing kelompok. (2) pada tahap elaborasi pendidik menunjuk kelompok siswa secara bergilir untuk menganalisis gambar-gambar yang ada baik itu memasangkan ataupun mengurutkan gambar sesuai fungsinya, pendidik memberikan pertanyaan mengenai alas an peserta didik dalam menentukan fungsi atau urutan gambar, dan pendidik mengembangkan materi dan menanamkan konsep materi yang sesuai dengan kompetensi yang ingin dicapai, serta pendidik melakukan penilaian terhadap kegiatan diskusi peserta didik. (3) Pada tahap konfirmasi pendidik memberikan tanggapan dan penguatan terkait dengan hasil analisa peserta didik, pendidik mengintruksikan kepada peserta didik menyempurnakan hasil analisanya, pendidik memberikan reward kepada kelompok pada peserta didik yang rajin, Pendidik memberikan kesempatan kepada peserta didik untuk mengajukan pertanyaan terkait materi yang telah di bahas, dan pendidik memeberikan feedback kepada peserta didik yang bertanya.Kegiatan Penutup adalah pendidik bersama peserta didik menyimpulkan mengenai materi yang telah di bahas dan pendidik memberikan arahan terkait materi yang akan dipelajari pada pertemuan berikutnya.

3. Tahap Observasi dan Evaluasi

Kegiatan ini dilakukan selama pelaksanaan tindakandengan mengobservasi motivasi dan hasil belajar siswa selama proses pembelajaran berlangsung adalah sebagai berikut (a) mengamati aktivitas belajar siswa terhadap model pembelajaran Picture and Picture. (b) memberikan angket tentang motivasi belajar kepada siswa (angket motivasi terlampir), (c) mencatat kekurangan saat pembelajaran dengan menggunakan model pembelajaran Picture and Picture.

4. Tahapan Refleksi

Pada tahap ini, hal-hal yang diidentifikasi seperti sejauh mana hasil yang dicapai, kelemahan dan kendala yang dialami, kemudian menjadi bahan pertimbangan yangakan didiskusikan dan dicarikan alternatif pemecahannya. Hal ini dilakukan sebagai bahan pertimbangan pada pelaksanaan pembelajaran di siklus berikutnya.

\section{HASIL DAN PEMBAHASAN}

Berdasarkan hasil analisis
terhadap proses pelaksanaan implementasi model Picture and Picture pada siklus I dan II, terungkap bahwa pembelajaran pada siklus । belum optimal. Motivai belajar siswa pada siklus I berada pada kategoripositif dengan skor rata-rata sebesar 68,71. Ketuntasan klasikal hasil belajar siswa pada siklus I sebesar $6,7 \%$ dengan nilai rata-rata yaitu 70,90 , dari 30 siswa terdapat 28 siswa mendapatkan nilai di bawah KKM sehingga belum dapat dikatakan tuntas karena satu kelas dikatakan tuntas jika sudah memenuhi ketuntasan klasikal $75 \%$. Siswa yang memiliki motivasi kategori cukup disebabkan oleh beberapa hal. Pertama, sedikitnya waktu pratik langsung sehingga pelajaran yang diterima sangat kurang yang diakibatkan kurangnya media pembelajaran seperti laptop. Kedua, tidak adanya kesadaran diri dari siswa dalam kesiapan mengikuti pembelajaran, sehingga siswa kebingungandalam mempelajari materi. Ketiga, uasana kelas yang kurang kondusif, karena masih ada siswa yang suka mengganggu temannya saat mengikuti pembelajaran sehingga kelas menjadi gaduh. Hal tersebut dapat mempengaruhi motivasi siswa yang ingin serius belajar sehingga menjadi terganggu minat untuk belajarnya. 
Hal-hal yang menyebabkan siswa belum mencapai ketuntasan klasikal yaitupertama, saat guru membimbing siswa ketika menindaklanjuti permasalahan, siswa tidak fokus mendengarkan informasi yang disampaikan guru, seperti berbicara dengan teman satu bangkunya, sehingga mereka tidak mengerti materi yang dipelajarinya. Kedua,pada saat kegiatan diskusi berlangsung, masih ada siswa yang asyik berbicara dengan teman satu kelompoknya membahas halhal yang tidak ada kaitannya dengan pelajaran sehingga menyebabkan siswa tersebut kurang fokus terhadap pelajaran. Ketiga, ada siswa yang hanya diam saja tidak membantu kelompoknya melakukan praktikum ataupun menjawab LKK, namun menyerahkannya kepada teman satu kelompok, sehingga siswa tersebut tidak mengerti materi tersebut. Keempat, ada siswa yang masih kurang aktif bertanya jika hal-hal yang kurang mereka pahami sehingga siswa tersebut belum menguasai konsep yang diajarkan. Kelima, sebelum dilakukannya tes, guru menanyakan kesiapan siswa untuk mengikuti tes tersebut. Namun ada beberapa siswa yang masih menjawab tidak siap untuk mengikuti tes karena belum belajar.

Penerapan model Picture and Picture pada siklus I ini mengalami satu kendala, yaitu jumlah alat dan bahan yang terbatas dan tidak sesuai dengan perencanaan pembelajaran sehingga perlu dicarikan alternatif solusi. Segalabentuk ketidak optimalan yang terjadi pada siklus I ini kemudian dapat menjadi bahan refleksi dalam upaya perbaikan pada siklus II.

Berdasarkan hasil penelitian pada siklus II, terungkap bahwa terjadi perubahan motivasi dan hasil belajar TIK siswa dari siklus I. Hasil penelitian menunjukkan bahwa tingkat motivai belajar siswa pada siklus II berada pada kategori positif dengan skor rata-rata sebesar 72,69. Ketuntasan klasikal hasil belajar siswa pada siklus II sebesar $100 \%$ dengan nilai rata-rata yaitu 90,14 , dari 30 siswa, tidak terdapat siswayang tidak tuntas.

Berikut profil hasil belajar siswa pada siklus I.

\begin{tabular}{|l|c|}
\hline Aspek & $\begin{array}{c}\text { Nilai Hasil } \\
\text { Belajar TIK }\end{array}$ \\
\hline Mean Hasil Belajar & 70,90 \\
\hline Nilai Tertinggi & 77,2 \\
\hline Nilai Terendah & 50,9 \\
\hline Frekuensi nilai $\geq 76$ & 2 \\
\hline Frekuensi nilai $<76$ & 28 \\
\hline Kategori & Sangat rendah \\
\hline $\begin{array}{l}\text { Persentase Tingkat } \\
\text { Hasil Belajar (\%) }\end{array}$ & 6,7 \\
\hline $\begin{array}{l}\text { Ketuntasan Belajar } \\
(\%)\end{array}$ & \\
\hline
\end{tabular}

Berikut profil hasil belajar siswa pada siklus II.

\begin{tabular}{|l|c|}
\hline Aspek & $\begin{array}{c}\text { Nilai Hasil } \\
\text { Belajar TIK }\end{array}$ \\
\hline Mean Hasil Belajar & 85,94 \\
\hline Nilai Tertinggi & 88,42 \\
\hline Nilai Terendah & 84,11 \\
\hline Frekuensi nilai $\geq 76$ & 30 \\
\hline Frekuensi nilai $<76$ & 0 \\
\hline Kategori & Sangat tinggi \\
\hline $\begin{array}{l}\text { Persentase Tingkat } \\
\text { Hasil Belajar (\%) }\end{array}$ & 85,94 \\
\hline Ketuntasan Belajar (\%) & 100 \\
\hline
\end{tabular}

Peningkatan motivasi dan hasil belajar TIK dikarenakan siswa sudah terbiasa dengan model yang diterapkan pada saat pembelajaran dan siswa menjadi lebih memahami dan bisa memvisualkan materi pelajaran dengan gambar-gambar yang telah dibagikan. Adapun kendala dalam penerapan model Picture and Picture pada siklus II ini adalah adanya indikator yang sulit diimplementasikan dengan Gambarsehingga pemecahan masalah dilakukan dengan cara berdiskusi 
langsung yang membutuhkan sedikit banyak waktu dikarnakan kekurangan mediapembelajaran seperti laptop.

Terdapat kenaikan hasil belajar siswa dari siklus I ke siklus II yang disebabkan oleh fase-fase pembelajaran pada model Picture And Picture yang memfasilitasi pengetahuan, pemahaman, aplikasi, dan analisis melalui kegiatan atau pengalaman praktikum, diskusi, kerja kelompok, dan presentasi.

Berikut grafik peningkatan motivasi belajar dan hasil belajar siswa dengan diterapkannya model pembelajaran Picture and picture.

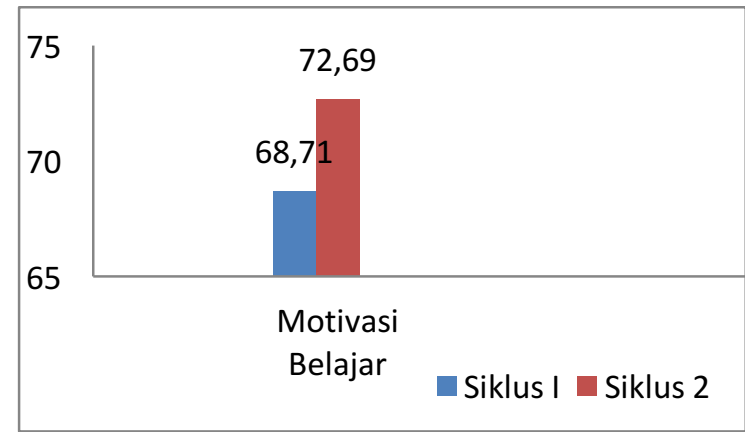

Gambar2. Grafik Motivasi Belajar

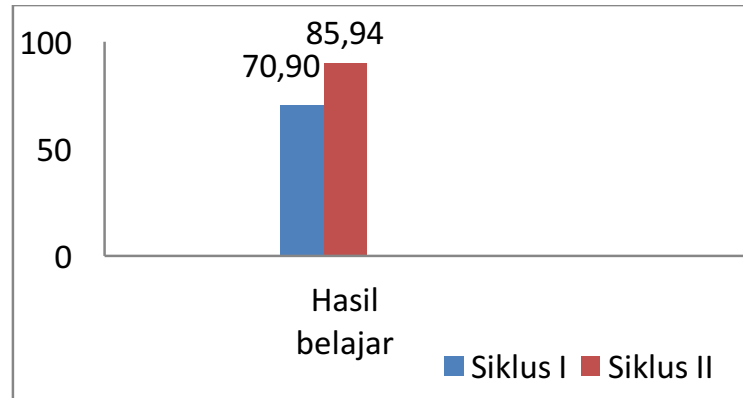

\section{Gambar 3. Grafik Hasil Belajar}

Pembelajaran model Picture and Picture ini merupakan salah satu model pembelajaran Kooperatif yang menggunakan gambar dengan cara memasangkan atau mengelompokkan dan sebagainya. Metode pembelajaran ini memiliki cirikreatif, inovatif dan menyenangkan. Model pembelajaran ini menuntut siswa untuk menciptakan suatu inovasi yang baru yang mendorong kesenangan anak dengan belajar dari sebuah masalah serta menyelesaikannya sesua dengan metode dan cara yang dimiliki oleh setiap peserta didik yang didapat dari pembelajaran yang diperoleh dari proses pembelajaran Hamdani dalam (Sidauruk, 2016). Media gambar yang digunakan dalam model pembelajaran ini merupakan pendukung paling utama dalam kegiatan pembelajaran. Oleh karena itu guru sudah mempersiapkan gambar yang akan digunakan sesuai dengan konsep pembelajaran, gambar boleh berbentuk charta ukuran besar dan kartu.

Hal ini sejalan dengan penelitian yang dilakukan oleh Luh Sri Suwastin (2014) menemukan bahwa model kooperatif tipe Picture and Picture memberi efek positif bagi motivasi belajar siswa untuk meningkatkan motivasi belajar siswa. Model pembelajaran kooperatif tipe Picture and Picture memotivasi siswa agar tertarik mempelajari TIK karena dengan belajar dengan media gambar dapat menarik minat belajar siswa. Pembelajaran tersebut juga memotivasi siswa sehingga dapat memecahkan masalah yang berkaitan dengan permasalahan TIK seperti kuran tersedianya sarana pembelajaran patikum seperti laptop/komputer. Belajar menggunakan model kooperatif tipe Picture and Picture selalu lebih baik dibandingkan dengan pembelajaran konvensional. Demikian juga hasil belajar siswa yang memiliki motivasi belajar tinggiakan selalu lebih baik daripada hasil belajar daripada hasil belajar siswa yang memiliki motivasi belajar rendah.

Penelitianini dilaksanakan oleh Erina (2016) menemukan bahwahasil belajar dan motivasi belajar siswa dapat meningkat dengan menerapkan model pembelajaran kooperatif tipe Picture and Picture. Belajar berbasis gambar 
mempengaruhi hasil siswa dalam aspek kognitif (Chandra, 2016). Penelitian yang dilakukan oleh Chandra (2016) menemukan bahwa model pembelajaran Picture and Picture lebih baik dibandingkan dengan siswa yang dibelajarkan dengan model pembelajaran lain.

Selain keberhasilan yang telah dicapai dengan penerapan model Picture And Picture di kelas VIII SMP Negeri 3 Seririt tahun pelajaran 2017/2018, terdapat beberapa kendala umum yang ditemui. Kendala yang dihadapi dalam penerapan model Picture And Picture di kelas VIII SMP Negeri 3 Seririt tahun pelajaran 2017/2018 terkait dengan penerapan model Picture And Picture tersebut, antara lain: pertama,terdapat materi pembelajaran yang tidak dapat dibuatkan di implementasikan dengan gambar sehingga harus dijelaskan dan dipraktikkan langsung sehingga membuat kekurang waktu karena media pembelajaran seperti laptop sangat kurang. Kedua, masih banyak siswa yang tidak serius dalam hal melakukan pratikum sehingga banyak yang belum bisa mempraktikan ketika disuruh.

\section{SIMPULAN DAN SARAN}

Berdasarkan hasil penelitian tindakan kelas yang dilaksanakan di kelas VIII B SMP N 3 Seririt Kecamatan Seririt Kabupaten Buleleng Yang telah diuraikan maka dapat disimpulkan bahwa sebagai berikut. (1) Penerapan model pembelajaran kooperatif tipe Picture And Picture dalam pembelajaran TIK dapat meningkatkan motivasi belajar siswa kelas VIII B SMP Negeri 3 Seririt tahun pelajaran 2017/2018 yang berada pada kategori positif. Hal ini dapat dilihat dari skor rata-rata motivasi belajar siswa pada akhir siklus I sebesar 68,71. Pada akhir siklus II skor rata-rata motivasi belajar siswa sebesar 72,69. (2) Penerapan kooperatif tipe Picture And Picture dalam pembelajaran TIK dapat meningkatkan hasil belajar siswa kelas VIII B SMP Negeri 3 Seririt tahun pelajaran 2017/2018. Secara klasikal pada akhir siklus I sebesar $6,7 \%$ berada pada kategori sangat rendah dengan nilai ratarata 70,90. Pada akhir siklus II secara klasikal sebesar $100 \%$ berada pada kategori baik dengan nilai rata-rata 85,94.

Berdasarkan hasil dan pembahasan yang telah dilaksanakan serta temuan-temuan yang diperoleh selama penelitian, maka dapat diajukan beberapa saran guna meningkatkan kualitas pembelajaran TIK ke depan yaitu sebagai berikut. (1) Peneliti menyarankan kepada guru agar Penerapan Model Pembelajaran Kooperatif Tipe Picture and Picture dapat dijadikan pilihan untuk meningkatan mutu pembelajaran dan hasil belajar siswa. (2) Peneliti menyarankan kepada siswa agar aktif dalam berpatisipasi dalam proses pembelajaran dan saling bekerjasama dalam memecahkan suatu permasalahan yang ada di dalam maupun di luar kelas serta dapat menciptakan rasa kebersamaan dalam proses pembelajaran agar mamu meningatkan motivasi belajar siswa. (3) Peneliti menyarankan kepada Kepala Sekolah untuk membina para guru dalam memilih dan menerapkan model pembelajaran yang efektif dan efesien sehingga dapat meningkatkan motivasi dan aktivitas belajar siswa. (4) peneliti menyarankan kepada peneliti lain hendaknya dapat melaksanakan PTK dengan berbagai model dan media pembelajaran lain yang belum sepenuhnya dapat terjangkau dalam penelitian ini, dengan adanya hasil penelitian ini dapat digunakan sebagai rujukan dan pembanding oleh penelitianpenelitian lebih lanjut dengan subjek, desain, dan variabel yang spesifik.

\section{DAFTAR PUSTAKA}

[1] Aeni, U., Chandra, E., Muspiroh,N, (2016), Identifikasi Kesulitan Guru Biologi Dalam Melaksanakan 
Pembelajaran Kurikulum 2013 Di SMA Negeri 1 Susukancirebon, Jurnal Sains dan Pendidikan Sains 5 (2): 165-174

[2] B. Uno, \& Hamzah (2008). Teori Motivasi Dan Pengukurannya. Jakarta: Bumi Aksara.

[3] Erina, Ni Putu Dewik dan Wayan Suartana. (2016). Pengaruh Partisipasi Penganggaran, Penekanan Anggaran, Kapasitas Individu, dan Kejelasan Sasaran Anggaran Pada Senjangan Anggaran. SSN: 2302-8556 EJurnal Akuntansi Universitas Udayana Vol.15.2. Mei (2016): 973-1000.

[4] Handayani. (2013). Penerapan Model Pembelajaran Picture Berbantuan Spesimen Pada Materi Invertebrata. Unnes Journal Of Biology Education.

[5] Kurniasih, I. d. (2015). Ragam Pengembangan Model Pembelajaran. Jakarta: Kata Pena.

[6] Miyono, Gendro (2011). Merancang Penelitian Bisnis dengan Alat Analisis SPSS17.0 \& Smart PLS 2.0. Yogyakarta: Percetakan STIM YKPM

[7] Sanjaya, W. (2006). Strategi Pembelajaran. Jakarta: Kencana Prenada Media Group.

[8] Sidauruk, E. M. (2016). Penerapan Metode Picture and Picture dalam meningkatkan motivasi dan hasil belajar siswa tentang materi keanekaragaman Makhluk Hidup Pada Kelas VIIB SMP Taman Dewasa Ibu Pawiyatan Yogyakarta. Yogyakarta: Program Studi Pendidikan Biologi Jurusan Pendidikan Matematika Dan IImu Pengetahuan Alam Fakultas Keguruan dan IImu Pendidikan Universitas Sanata Dharma.
[9] Thobroni, M., \& Arif, M. (2011). Belajar dan Pembelajaran. Yogyakarta: AR-RUZZ MEDIA.

[10] B. Uno, Hamzah. 2008. Teori Motivasi dan Pengukurannya, Jakarta : Bumi Aksara. 